\title{
Secondary Structure Changes and Thermal Stability of Plasma Membrane Proteins of Wheat Roots in Heat Stress
}

\author{
Xin Zhao ${ }^{1}$, Yong Shi ${ }^{1}$, Li Chen ${ }^{2}$, Fenlin Sheng ${ }^{3}$, Haiyan Zhou ${ }^{1}$ \\ ${ }^{1}$ Laboratory of Plant Stress Ecophysiology and Biotechnology, Cold and Arid Regions Environmental and Engineering Research \\ Institute, Chinese Academy of Sciences, Lanzhou, China; ${ }^{2}$ College of Life Science and Engineering, The Northwest University for \\ Nationalities, Lanzhou, China; ${ }^{3}$ Instrumental Analysis and Research Center, Lanzhou University, Lanzhou, China. \\ Email: zhaox@lzb.ac.cn
}

Received July 21 ${ }^{\text {st }}$, 2011; revised August 20 ${ }^{\text {th }}, 2011$; accepted September $6^{\text {th }}, 2011$.

\begin{abstract}
The wheat roots membrane separates the cell from the environment around it and encloses the cell contents. The protein secondary structure and thermal stability of the plasma membrane of wheat root have been characterized in $\mathrm{D}_{2} \mathrm{O}$ buffer from $20^{\circ} \mathrm{C}$ to $90^{\circ} \mathrm{C}$ by Attenuated total reflection Fourier transform infrared spectroscopy (ATR-FTIR). Quantitative analysis of the amide I band $\left(1700-1600 \mathrm{~cm}^{-1}\right)$ showed that the plasma membrane proteins contains $41 \% \alpha$-helix, $16 \% \beta$-sheet, $18 \%$ turn, and $25 \%$ disorder structures at $20^{\circ} \mathrm{C}$. At elevated temperatures from $25^{\circ} \mathrm{C}$ up to $90{ }^{\circ} \mathrm{C}$, the $\alpha$-helix and the $\beta$-sheet structure unfold into turns and the disorder structure, with a major conformational transition occurring at $50^{\circ} \mathrm{C}$. There is a rapid decline in $\mathrm{H}^{+}$-ATPase activity of plasma membrane from $35^{\circ} \mathrm{C}$ to $55^{\circ} \mathrm{C}$ and it remain very low level $H^{+}$-ATPase activity of $P M$ from $55^{\circ} \mathrm{C}$ to $90^{\circ} \mathrm{C}$. Therefore the protein conformational transition was one of reasons of loses $H^{+}$-ATPase activity of plasma membrane.
\end{abstract}

Keywords: Plasma Membrane, Heat Stress, Protein Second Structure, ATR-FTIR

\section{Introduction}

The plant plasma membrane (PM) separates the cell from the environment around it and encloses the cell contents. It has four important functions: it acts as a semi-permeable barrier, it regulates transport in and out of the cell; and it provides communication and adhesion. It is the first line of cell defense against the stress from the outside environment and against harmful free radicals.

The heat sensitivity of the PM has both practical and theoretical significance. The study of the heat denaturation process can provide an insight into the structural organization and individual roles of proteins in general. More specifically, heat can induce functional change in the plant PM [1]. A review by Arrondo [2] descripted the applications of IR spectroscopy to the study of membrane proteins. Shi [3] reported a study on FT-IR of the secondary structure and conformational changes of a photosystem II (PS II) membrane and core complex during heat denaturation. The core of the PS II denatured from $55^{\circ} \mathrm{C}$ to $65^{\circ} \mathrm{C}$ with transitions of the secondary structure from co-helix and turns to $\beta$-sheet and random coils. The denaturation of light-harvesting chlorophyll protein (LHCP) began at $65^{\circ} \mathrm{C}$ and was characterized by a rapid increase of the turns. However, the above studies were restricted by a lack of information on the conformational changes of proteins during heat denaturation; such information is necessary for an understanding of the mechanism of the heat inactivation of the PM.

Attenuated total reflection Fourier transform infrared spectroscopy (ATR-FTIR) is one of the most powerful tools for recording infrared spectra of biological materials in general, and for biological membranes in particular. It has fast speed, yields a strong signal with only a few micrograms of sample, and most importantly it allows information about the orientation of various parts of the molecule under study to be evaluated in an oriented system. The environment of the molecules can be modulated so that their conformation can be studied as a function of temperature, pressure and $\mathrm{pH}$, as well as in the presence of species ligands. Because of the long IR wavelength, light scattering problems are virtually non-existent and highly aggregated materials or large membrane fragments can be investigated. A unique advantage of infrared spec- 
troscopy is that it allows simultaneous study of the structure of lipids and proteins in intact biological membranes without introduction of foreign perturbing probes [4]. Some types of analysis of infrared data are claimed to provide highly accurate quantitative estimates of the content of secondary structures, with a standard deviation as low as $2 \%$ - $3 \%$ with respect to the corresponding $\mathrm{X}$-ray structures. The advantage of FTIR is that protein secondary structure is measured in the native environment of the proteins and that it is a noninvasive technique. FTIR spectroscopy is a unique possibility for the simultaneous study of protein and lipid structures and dynamics in biological membranes [5,6]. Differences in the C-O stretching vibrations of the peptide groups (the amide-I region between $1600-1700 \mathrm{~cm}^{-1}$ ) provide information on the type of secondary structure, such as $\alpha$-helix, $\beta$-strands, disorder and different kinds of turn structures [7].

The processes controlling plant growth and survival in a hostile environment might be clarified at molecular and cellular level. Therefore, we examine the effect of heat

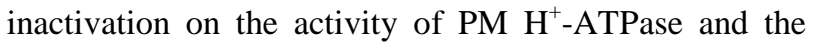
$\mathrm{PM}$ protein, and investigate the changes in the protein secondary structure of PM in response to high temperatures by FTIR.

\section{Material and Methods}

\subsection{Plant Materials}

Wheat seeds (Triticum aestivum var. Longchun No. 20, purchased from Gansu Agriculture Sciences Academy, China) were sterilized in 1\% sodium hypochlorite (Na$\mathrm{ClO})$ solution for $20 \mathrm{~min}$, then soaked in water for $24 \mathrm{~h}$ and germinated in the dark at $25^{\circ} \mathrm{C}$ for $24 \mathrm{~h}$., The seedlings were grown for 10 days at $19^{\circ} \mathrm{C}$ in quartz sand and irrigated with tap-water. They were illuminated for $14 \mathrm{~h}$ each day with a light intensity of $100 \mu \mathrm{mol} \mathrm{m} \mathrm{m}^{-2} \cdot \mathrm{s}^{-1}$. Since the root plasma membrane is the site of absorption various nutrition, we harvested the purification of plasma membrane from wheat roots.

\subsection{Wheat Roots Plasma Membrane Isolation and Purification}

Wheat roots plasma membrane was prepared by twophase partition [8]. Roots were cut into pieces and immediately homogenized in the isolation medium containing $50 \mathrm{mM}$ HEPES-tris, pH 7.5, $250 \mathrm{mM}$ sucrose, $1 \mathrm{mM}$ EDTA, $0.6 \%$ PVP, $1 \mathrm{mM}$ PMSF, and $1 \mathrm{mM}$ DTT at $4^{\circ} \mathrm{C}$. The homogenate was filtered through four layers of cotton gauze and centrifuged (Beckman AJ-250) at 15,000 $\mathrm{g}$ for $15 \mathrm{~min}$. The supernatant was then centrifuged (Beckman AJ-250) at $80,000 \mathrm{~g}$ for $60 \mathrm{~min}$ in order to obtain a microsomal pellet, which was resuspended in a buffer containing $0.048 \%$ potassium phosphate ( $\mathrm{pH} 7.8)$.
The suspension was then added to a phase mixture to obtain a phase system consisting of $0.048 \%$ potassium phosphate (pH 7.8), 6.2\% PEG-3350, 6.2\% dextran T$500,0.015 \% \mathrm{KCl}$, and $250 \mathrm{mM}$ sucrose. After it was centrifuged at $1000 \mathrm{~g}$ for $5 \mathrm{~min}$ for three times, the final upper phases were collected, diluted at least twice with $50 \mathrm{mM}$ HEPES-tris, pH 7.4, $250 \mathrm{mM}$ sucrose, $1 \mathrm{mM}$ EDTA, $1 \mathrm{mM}$ DTT, and $1 \mathrm{mM}$ PMSF, and centrifuged for $60 \mathrm{~min}$ at $80,000 \mathrm{~g}$. The resulting pellet was resuspended in $50 \mathrm{mM}$ Tris- $\mathrm{HCl} \mathrm{pH}$ 7.4, $250 \mathrm{mM}$ sucrose, 1 mM EDTA, $1 \mathrm{mM}$ DTT, and $1 \mathrm{mM}$ PMSF. All the above steps were carried out at $4^{\circ} \mathrm{C}$. Plasma membrane pellets were used immediately to obtain ATR-FTIR spectral.

\subsection{PM Heat Treatment}

Polarized attenuated total internal reflection infrared spectroscopy is one of the best tools available for obtaining information on the orientation of peptides interacting with membranes. The method is simple (oriented multilayer systems are easily obtained by drying a membrane suspension on the internal reflection element). It is sensitive (less than $1 \mathrm{mg}$ of peptide is required to form a single monolayer) and it does not require specific labeling. To remove the spectral interference from $\mathrm{H}_{2} \mathrm{O}$ absorption bands (OH- bond strongly absorbed on amide I 1600 $1700 \mathrm{~cm}^{-1}$ ), the PM samples were dissolved in an identical concentration but $\mathrm{D}_{2} \mathrm{O}$-based buffer.

Heat inactivation was performed by incubating a purified $\mathrm{PM}$ sample on a $\mathrm{CaF}_{2}$ plate in a temperature bath (Yamato-Komatsu Coolnics circulator CTE-24A) in steps of $5^{\circ} \mathrm{C}$ from $20^{\circ} \mathrm{C}$ to $90^{\circ} \mathrm{C}$. After every heating step, the PM sample was left to stabilize for 5 min and then immediately subjected to ATR-FTIR measurement, and then increased temperature in the step $5^{\circ} \mathrm{C}$.

The spectrum was obtained on an OMNI sampler of a Fourier Transform Infrared spectrometer (Nexus 670; Nicolet, Madison, WI) with germanium plane in a $2 \mathrm{~mm}^{2}$ sensing area. Attenuated total reflection infrared (ATRFTIR) spectra were recorded on an OMNIC sampling instrument. The internal reflection element was a germanium ATR plate $(50 \times 20 \times 2 \mathrm{~mm})$ with an aperture angle of $45^{\circ}$. In total, 128 scans were accumulated for each spectrum. Spectra were recorded at a nominal resolution of $2 \mathrm{~cm}^{-1}$.

\subsection{Assay of $\mathbf{H}^{+}$-ATPase Activity}

Heat inactivation was performed by incubating a purified PM sample in tubes that puted in Dri-Block Heater (DB2D Digital, United Kindom) in steps of $5^{\circ} \mathrm{C}$ from $20^{\circ} \mathrm{C}$ to $90^{\circ} \mathrm{C}$ (three repeats). After every heating step, the PM sample was left to stabilize for $5 \mathrm{~min}$ and then measure its $\mathrm{H}^{+}$-ATPase activity as same treatment as the method in 2.3. ATP hydrolysis assays were performed as de- 
scribed by Ohinishi [9]. Membrane proteins (10 - $15 \mu \mathrm{g})$ were added to $0.5 \mathrm{ml}$ of reaction medium containing 25 mM HEPES-Tris (pH 6.5), 3 mM ATP, 50 mM KCl, 1 $\mathrm{mM}$ Na3MoO4, and $0.015 \%(\mathrm{w} / \mathrm{v})$ Triton X-100, in the presence or absence of $400 \mu \mathrm{M} \mathrm{Na} \mathrm{VO}_{4}$. After $30 \mathrm{~min}$ incubation at $37^{\circ} \mathrm{C}$, the reaction was quenched by the addition of $10 \%(\mathrm{w} / \mathrm{v})$ TCA. The $\mathrm{H}^{+}$-ATPase activity was determined by measuring the release of Pi [9]. Protein in the plasma membranes was measured by the method of Bradford [10] with bovine serum albumin as the standard.

\subsection{FTIR Spectral Data Analysis}

The IR Data Manager analytical software of OMNIC (Version 6.0; Nicolet, USA) was used to obtain original and Fourier self-deconvolution spectra and second-derivative spectra.

The parameters for the Fourier self-deconvolution procedure were a smooth factor of 15.0 and a width factor of $10.0 \mathrm{~cm}^{-1}$, using the interactive OMNIC 6.0 tool for Fourier self-deconvolution. The line width in the deconvolved spectrum was chosen carefully to avoid introduction of erroneous bands [11]. The second-derivative spectrum was normalized, and the band position was calculated as the average of the spectral positions at $80 \%$ of the total peak height. They were smoothed over 15 data points.

The water spectra to be subtracted were collected under the same conditions as the membrane spectra. Criteria for the correctness of subtraction were removal of the band near $2200 \mathrm{~cm}^{-1}$ and flat baseline between 1800 and $2000 \mathrm{~cm}^{-1}$ for samples in $\mathrm{H}_{2} \mathrm{O}$ and elimination of the strong band at $1209 \mathrm{~cm}^{-1}$ for samples in $\mathrm{D}_{2} \mathrm{O}$, avoiding negative side lobes. Second-derivative and deconvolution spectra were used to determine the number and the positions of the bands as starting parameters for the curvefitting procedure, assuming Pearson or Voigt band shapes.

The band-fitting used Origin 7.0 software with an appended PFM (Peak Fitting Maximum) function and for protein studies the spectral region between 1800 and $1500 \mathrm{~cm}^{-1}$ was selected. This region contains the amide I and amide II absorption bands of the protein backbones. Band curve-fitting includes the decomposition of the amide I band into its constituents and the assignment of these components to protein structural features. To start the quantification process, the number and position of the bands and a rough estimation of band shapes, widths and heights of the components is needed. The Gaussian peak shape was used to fit the spectrum collected at each time point (Chi-square < 10 - 5). Band curve-fitting is best performed on original bands, although it is sometimes accomplished, less accurately, on more shapely spectra obtained through self-deconvolution or second derivation.

\section{Results and Discussion}

\subsection{High Temperatures Induced Inactivation of PM H ${ }^{+}$-ATPase}

An increase in temperature was accompanied by inhibittion of the $\mathrm{H}^{+}$-ATPase activity of the PM vesicles isolated from wheat roots (Figure 1), with a particularly sharp reduction as the temperature rose from $35^{\circ} \mathrm{C}$ to $50^{\circ} \mathrm{C}$, and it was remaining at a very low level from $50^{\circ} \mathrm{C}$ to $90^{\circ} \mathrm{C}$.

\subsection{Relationship of Band positions of Amide I with High Temperature Stress}

The most studied infrared band of proteins is the amide I band appearing between 1600 and $1700 \mathrm{~cm}^{-1}$, with a maximum for most proteins at around $1654-1674 \mathrm{~cm}^{-1}$. This arises primarily from the stretch vibration of the peptide $\mathrm{C}=\mathrm{O}$ group. Normal mode analysis reveals that the $\mathrm{C}=\mathrm{O}$ stretching couples slightly with $\mathrm{CN}$ stretching, $\mathrm{CN}$ deformation and $\mathrm{NH}$ bending. Unfortunately, the $\mathrm{HOH}$ bending motion of water almost coincides with the amide I band and makes studies in proton aqueous solution difficult [12]. This problem is overcome by using $\mathrm{D}_{2} \mathrm{O}$ as solvent. The $\mathrm{D}_{2} \mathrm{O}$ substitution leads to a shift of the amide I band (amide I) between 2 and $9 \mathrm{~cm}^{-1}$ to lower frequencies depending on the particular protein [13].

Because the $\mathrm{C}=\mathrm{O}$ group is involved in different secondary structure elements via hydrogen bonding to the peptide $\mathrm{NH}$ group, the experimentally observed amide I band envelopes a multitude of single bands with different frequencies which can be resolved as described above. The large number of infrared spectroscopic studies in com-

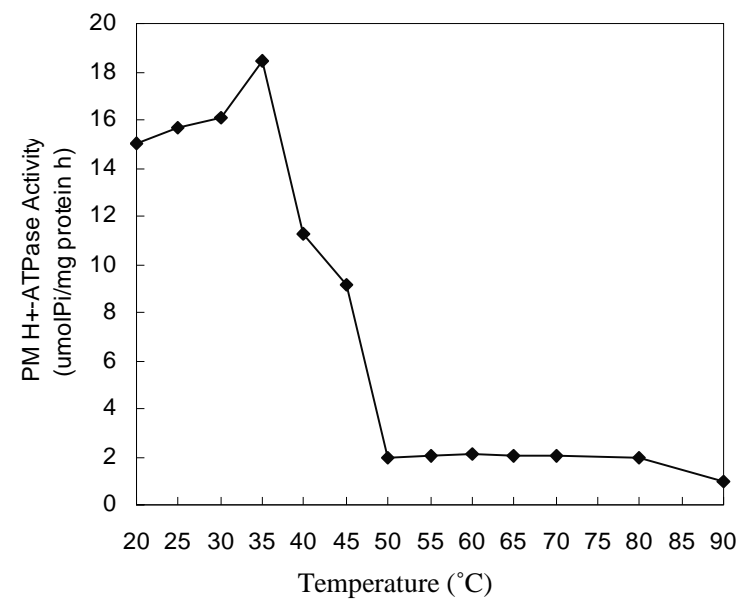

Figure 1. Inactivation of $\mathbf{H}^{+}$-ATPase in PM vesicles isolated from wheat roots. The $P M$ vesicles were heated from $20^{\circ} \mathrm{C}$ to $90^{\circ} \mathrm{C}$ with $10 \mathrm{~min}$ at every $5^{\circ} \mathrm{C}$ step, and then the $\mathrm{H}^{+}$ATPase activity was determined by measuring the release of $\mathrm{Pi}$. Values are mean $\pm \mathrm{SE}$ of at least four replicates. 
bination with crystal structure and NMR analyses on various proteins revealed some variability of the frequency of the assigned component amide I bands. However, one can generally classify the components between 1658 $\mathrm{cm}^{-1}$ to $\alpha$-helices [14,15], $1620-1635 \mathrm{~cm}^{-1}$ to intramolecular $\beta$-sheets, and $1665-1690 \mathrm{~cm}^{-1}$ to turns [11,14, 15]. However, aggregated proteins show intermolecular antiparallel $\beta$-sheets with infrared absorption around 1614 - $1624 \mathrm{~cm}^{-1}[11,14,15]$. Some exceptions from this general assignment have discussed in the recent review by Arrondo and Goni [3] and by Heimburg [16]. Table 1 summarizes published assignments of amide I components of the PM spectrum to secondary structure elements. Secondary structure composition can be estimated from the relative area of the single bands assigned to the different structures assuming that the extinction coefficient for the peptide CO stretch vibration is the same in all hydrogen bonding structures.

\subsection{Changes in Protein Secondary Conformation of PM Damaged under High Temperature Stress}

The original FTIR spectral band (Figure 2) often generated complex multi-component bands that overlap into a broad unresolved absorption. To quantitatively analyze the change in intensities of the amide I band, the IR spectra of the PM used Fourier self-deconvolution spectra and second-derivative spectra. The IR spectra of the PM were curve fitted with Origin 7.0 software with appended PFM (Peak Fitting Maximum) function. The Gaussian peak peak shape was used to fit the spectrum collected at each time point (Figure 3). The peaks belongs to the Amide I

Table 1. Frequencies and proposed structural assignments of the bands for the decomposition between 1700 and 1580 $\mathrm{cm}^{-1}$ in the infrared spectrum of the PM.

\begin{tabular}{|c|c|c|}
\hline Frequency $\left(\mathrm{cm}^{-1}\right)$ & Assignment & References \\
\hline 1704 & Ester C-O group & $\begin{array}{c}\text { Blume [17] } \\
\text { Menikh [18] }\end{array}$ \\
\hline 1693 & $\beta$-Sheet & He, WZ [19] \\
\hline 1665 & Turns & $\begin{array}{l}\text { Surewicz [20] } \\
\text { Dong [15] }\end{array}$ \\
\hline 1657 & $\alpha$-Helix & $\begin{array}{c}\text { He, WZ [19] } \\
\text { Dong [15] }\end{array}$ \\
\hline 1650 & $\begin{array}{c}\text { Random coil }+ \\
\text { loops }\end{array}$ & $\begin{array}{l}\text { Surewicz [18] } \\
\text { Dong [15] }\end{array}$ \\
\hline 1638 & $\beta$-Sheet & $\begin{array}{c}\text { He, WZ [19] } \\
\text { Surewicz [18] } \\
\text { Dong [14] }\end{array}$ \\
\hline 1628 & $\beta$-Sheet (strands) & $\begin{array}{c}\text { He, WZ [16] } \\
\text { Surewicz [18] } \\
\text { Dong [15] }\end{array}$ \\
\hline 1610 & $\begin{array}{l}\text { Side-chain } \\
\text { (tyrosine) }\end{array}$ & $\begin{array}{c}\text { He, WZ [19] } \\
\text { MacDonald [21] }\end{array}$ \\
\hline 1582 & Amide II band & $\begin{array}{c}\text { He, WZ [19] } \\
\text { Haris [13] }\end{array}$ \\
\hline
\end{tabular}

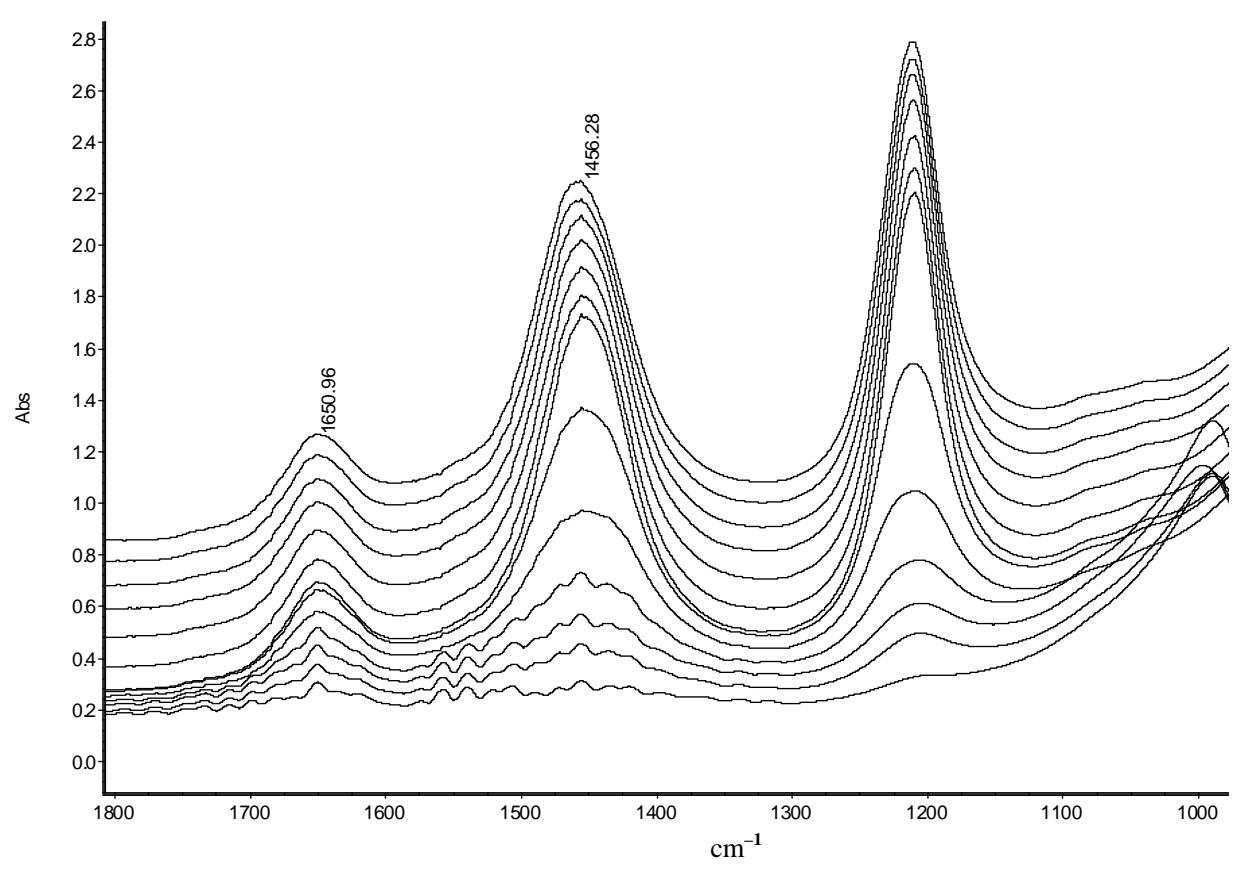

Figure 2. Change in the band region from 1800 to $1000 \mathrm{~cm}^{-1}$ in the infrared spectrum of the plasma membrane in $D_{2} O$ buffer during the stepped heating process. From upper to lower, the spectra are those at $20^{\circ} \mathrm{C}$ to $90^{\circ} \mathrm{C}$ with increasing temperature steps of $5^{\circ} \mathrm{C}$. 

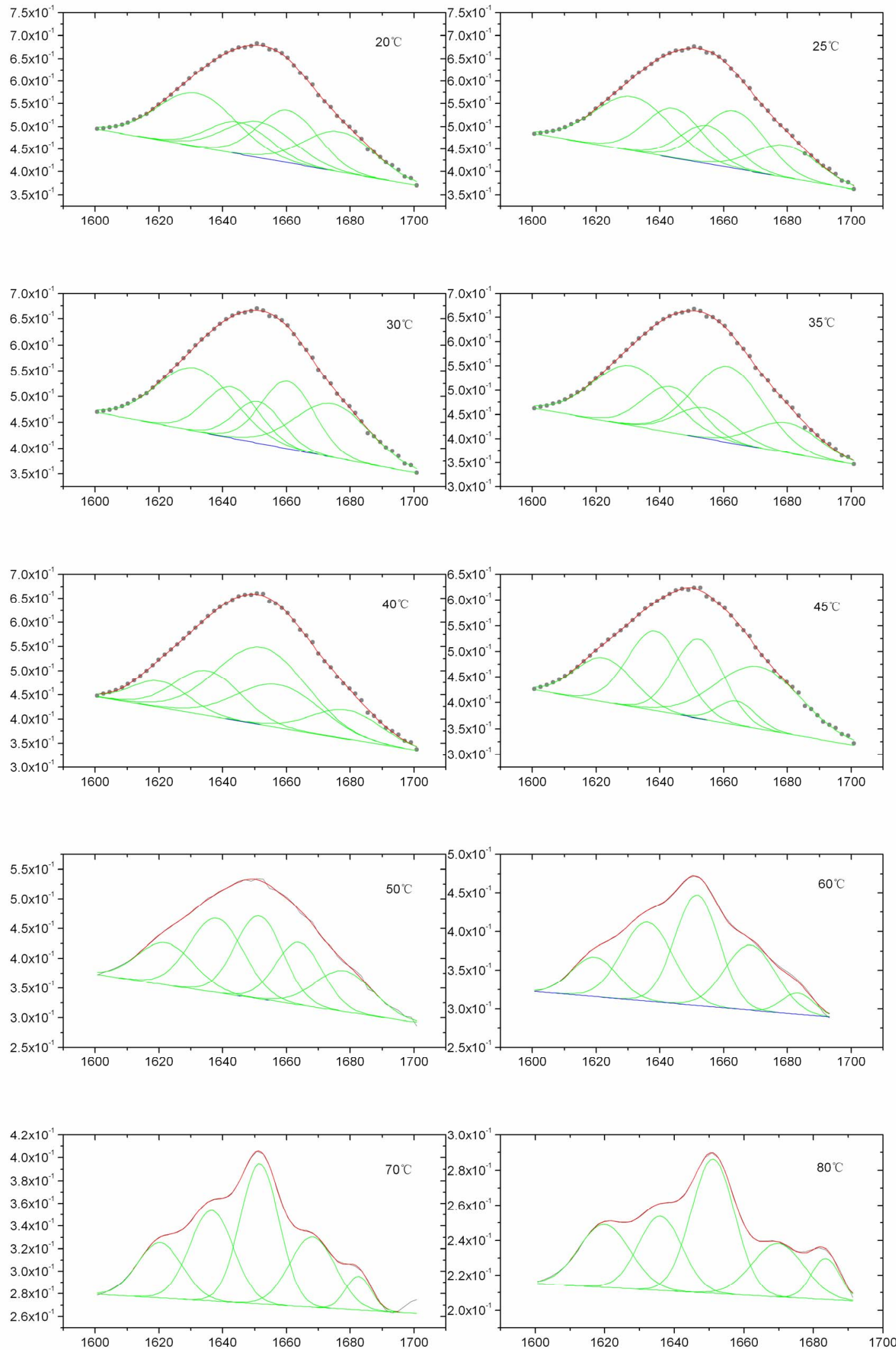

(a) 


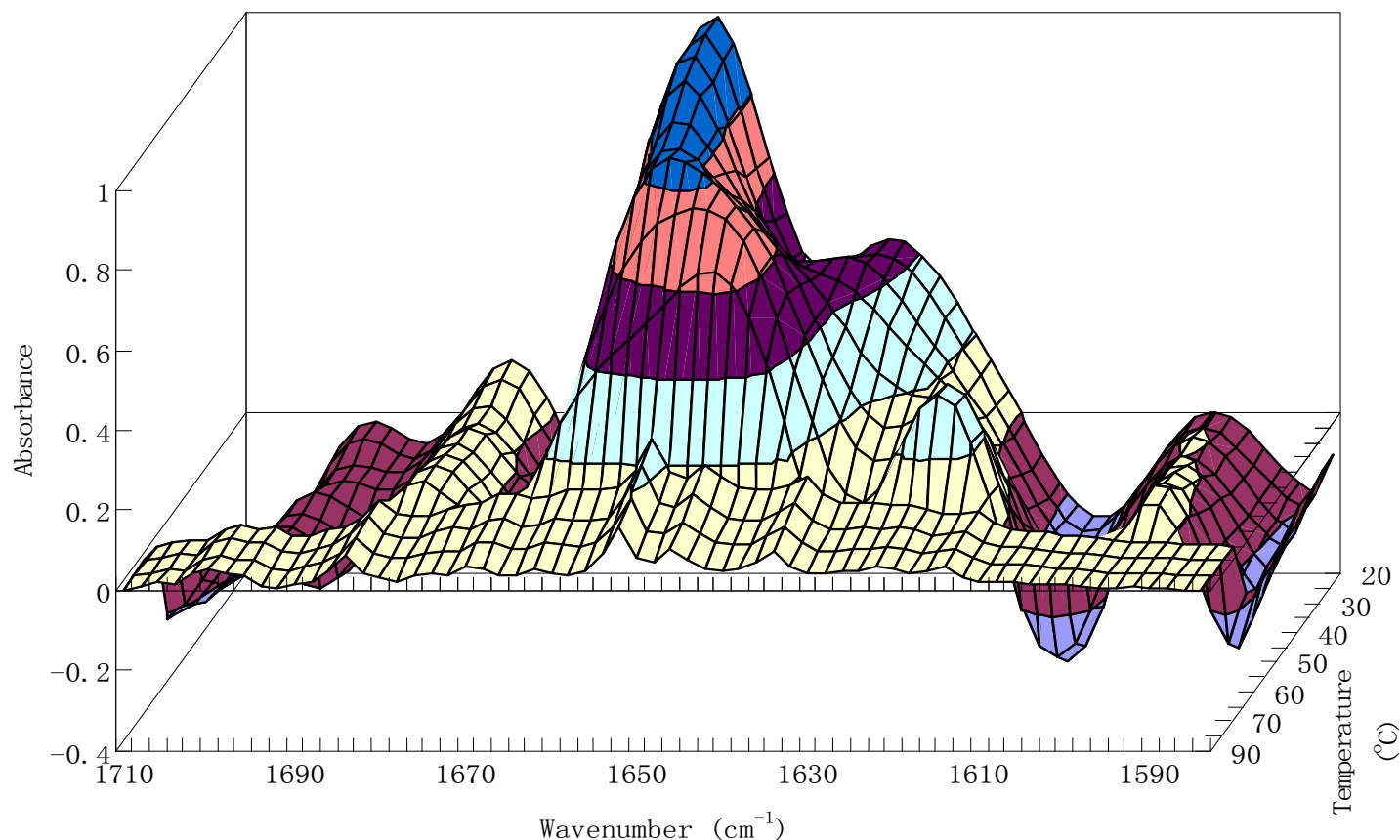

(b)

Figure 3. (a) Curve-fitting result of Amide $I$ from $20^{\circ} \mathrm{C}-80^{\circ} \mathrm{C}$. (b) Change of the amide $I$ band in the infrared spectrum of the plasma membrane during the stepped heating process. From inner to outer, the spectra recorded are those at increasing temperature steps of $5^{\circ} \mathrm{C}$.

band, the five main peaks contained 41\% $\alpha$-helix(1657 $\mathrm{cm}^{-1}$ ), $16 \% \beta$-sheet $\left(1638 \mathrm{~cm}^{-1}\right.$ and $\left.1693 \mathrm{~cm}^{-1}\right), 18 \%$ turn $\left(1665 \mathrm{~cm}^{-1}\right)$, and $25 \%$ disorder $\left(1650 \mathrm{~cm}^{-1}\right)$ structures at $20^{\circ} \mathrm{C}$.

The amide I band has been widely used to reveal the

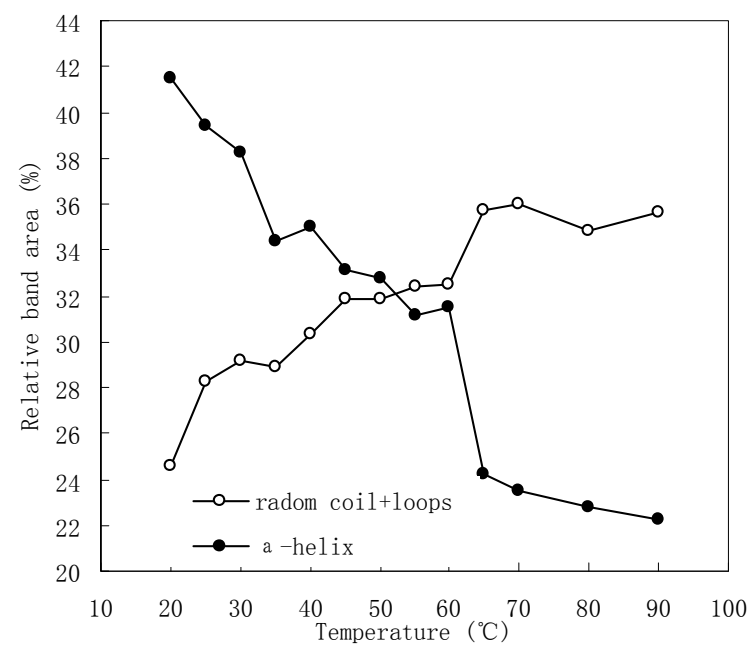

(a) secondary structure of proteins. At temperatures from $25^{\circ} \mathrm{C}$ to $90^{\circ} \mathrm{C}$, the $\alpha$-helix and the $\beta$-sheet structure unfold into the disorder structure and turns, with a major conformational transition occurring at $55^{\circ} \mathrm{C}$ (Figure 4). This leads to rapid decline of $\mathrm{H}^{+}$-ATPase activity from 35 to

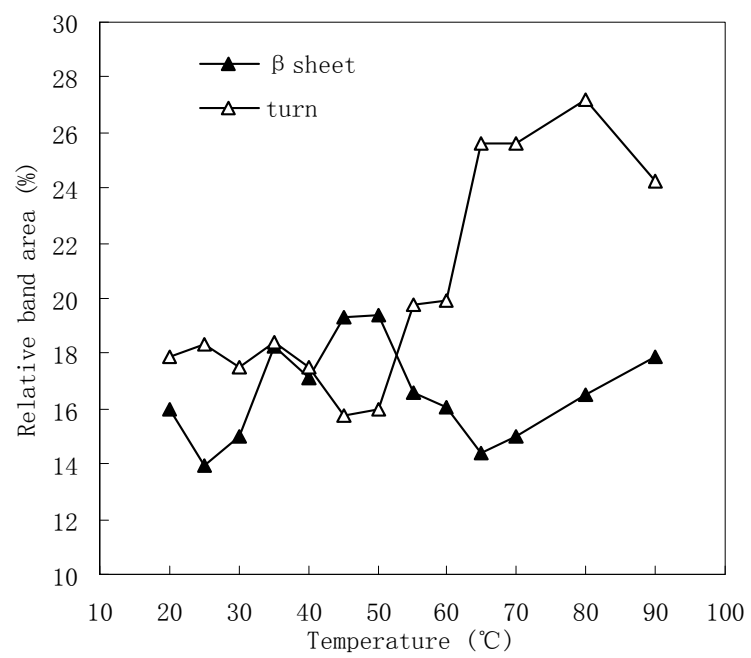

(b)

Figure 4. Changes in the secondary structure content of the plasma membrane during heat denaturation obtained by decomposition of the amide I band of the infrared spectrum. The $\beta$-sheet curve includes both $\beta$-sheet and extended chains $(\beta$-strands). The random coils and loops represent unordered structures and loops. Turns usually mean $\beta$-turns. (a) $\alpha$-helix and random coil loops content of PM. (b) $\beta$ sheet and turns content of PM. 
$90^{\circ} \mathrm{C}$.

$\mathrm{H}^{+}$-ATPase activity was positively correlated $\left(\mathrm{R}^{2}=\right.$ 0.6475 ) with the corresponding relative band area percentage of $\alpha$-helix in the amide I region. Therefore the protein conformational transition was one of reasons of loses $\mathrm{H}^{+}$-ATPase activity of PM.

\section{Acknowledgements}

This work is financially supported by NSFC (30770343, 30870383 and 31070360) research foundation.

\section{REFERENCES}

[1] A. S. Malik, O. Boyko, N. Atkar and W. F. Young, “A Comparative Study of MR Imaging Profile of Titanium Pedicle Screws,” Acta Radiologica, Vol. 42, No. 3, 2001, pp. 291-293. doi:10.1080/028418501127346846

[2] Y. L. Yang, F. Zhang, W. L. He, X. M. Wang and L. X. Zhang, "Iron-Mediated Inhibition of $\mathrm{H}^{+}$-ATPase in Plasma Membrane Vesicles Isolated from Wheat Roots," $\mathrm{Ce}$ llular and Molecular Life Science, Vol. 60, No. 6, 2003, pp. 1249-1257.

[3] J. L. R. Arrondo and F. M. Goñi, "Structure and Dynamics of Membrane Proteins as Studied by Infrared Spectroscopy,” Progress in Biophysics \& Molecular Biology, Vol. 72, 1999, pp. 367-405.

[4] H. Shi, L. Xiong, K. Y. Yang, C. Q. Tang, T. Y. Kuang and N. M. Zhao, "Protein Secondary Structure and Conformational Changes of Photosystem II during Heat Denaturation Studied by Fourier Transforminfrared Spectroscopy," Journal of Molecular Structure, Vol. 446, No. 1-2, 1998, pp. 137-147.

[5] E. Goormaghtigh, V. Raussens and J. M. Ruysschaert, "Attenuated Total Refection Infrared Spectroscopy of Proteins and Lipids in Biological Membranes," Biochimica et Biophysica Acta, Vol. 1422, 1999, pp. 105-185.

[6] A. M. Phelan and D. G. Lange, "Ischemia/Reperfusion -induced Changes in Membrane Fluidity Characteristics of Brain Capillary Endothelial Cells and Its Prevention by Liposomal-Incorporated Superoxide Dismutase,” Biochimica et Biophysica Acta, Vol. 1067, 1991, pp. 97-103.

[7] R. H. Sills, D. J. Moore and R. Mendelsohn, "Erythrocyte Peroxidation: Quantitation by Fourier Transform Infrared Spectroscopy," Analytical Biochemistry, Vol. 218, No. 1, 1994, pp. 118-123.

[8] H. Susi, S. N. Timasheff and L. Stevens, "Infrared Spectra and Protein Conformation in Aqueous Solutions: The Amide I Band in $\mathrm{H}_{2} \mathrm{O}$ and $\mathrm{D}_{2} \mathrm{O}$ Solutions," Jounral Biology Chemistry, Vol. 242, 1967, pp. 5460-5466.

[9] Q. S. Qiu and X. F. Su, "The Influence of Extra Cellular Side $\mathrm{Ca}^{2+}$ on the Activity of the Plasma Membrane $\mathrm{H}^{+}$ATPase from Wheat Roots," Australian Journal of Plant Physiology, Vol. 25, 1998, pp. 923-928.

[10] T. Ohinish, R. S. Gall and M. L. Mayer, “An Improved
Assay of Inorganic Phosphate in the Presence of Extralabile Phosphate Compounds: Application to the ATPase assay in the Presence of Phosphocreatine," Analytical Biochemistry, Vol. 69, 1975, pp. 261-267.

[11] M. M. Bradford, “A Rapid and Sensitive Method for the Quantization of Microgram Quantities of Protein Utilizing the Principle of Protein-Dye Binding," Analytical Biochemistry. Vol. 72, 1976, pp. 248-254. doi:10.1016/0003-2697(76)90527-3

[12] W. K. Surewicz and H. H. Mantsch, "New Insight into Protein Secondary Structure from Resolution-Enhanced Infrared Spectra," Biochimica et Biophysica Acta., Vol. 952, No. 2, 1988, pp. 115-130. doi:10.1016/0167-4838(88)90107-0

[13] K. Rahmelow and W. Hubner, "Infrared Spectroscopy in Aqueous Solution: Difficulties and Accuracy of Water Subtraction," Applied Spectroscopy, Vol. 51, No. 2, 1997, pp. 160-170. doi:10.1366/0003702971940080

[14] P. I. Haris, M. Coke and D. Chapman, "Fourier Transform Infrared Spectroscopic Investigation of Rhodopsin Structure and Its Comparison with Bacteriorhodopsin," Biochimica et Biophysica Act, Vol. 995, No. 2, 1989, pp. 160-167. doi:10.1016/0167-4838(89)90075-7

[15] A. Dong, P. Huang and W. S. Caughey, "Protein Seconddary Structures in Water from the Second Derivative Amide I Infrared Spectra,” Biochemistry, Vol. 29, 1990, pp. 3303-3308. doi:10.1021/bi00465a022

[16] T. Heimburg, J. Schunemann, K. Weber and N. Geisler, "FTIR-Spectroscopy of Multistranded Coiled Coil Proteins,” Biochemistry, Vol. 38, No. 39, 1999, pp. 1272712734. doi:10.1021/bi983079h

[17] A. Blume, W. Hubner and G. Messner, "Fourier Transform Infrared Spectroscopy of ${ }^{13} \mathrm{C}=\mathrm{O}$ Laber Phospholipids Hydrogen Bonding to Carbonyl Groups,” Biochemistry, Vol. 27, No. 21, 1988, pp. 8239-8249. doi:10.1021/bi00421a038

[18] A. Menikh and M. Fragata, "Fourier Transform Infrared Spectroscopic Study of Ion Binding and Intramolecular Interactions in the Polar Head of Digalac-tosyldiacylglycerol,” European Biophysics Journa, Vol. 22, No. 4, 1993, pp. 249-258. doi:10.1007/BF00180259

[19] W. Z. He, W. R. Newell, P. I. Haris, D. Chapman and J. Barber, "Protein Secondary Structure of the Isolated Photosystem II Reaction Center and Conformational Changes Studied by Fourier Transform Infrared Spectroscopy," Biochemistry, Vol. 30, No. 18, 1991, pp. 4552-4559. doi:10.1021/bi00232a027

[20] W. K. Surewicz and H. H. Mantsch, "Infrared Absorption Methods for Examining Protein Structure,” In: H. A. Havel, Ed., Spectroscopic Methods for Determining Protein Structure in Solution, VCH, New York, 1996, pp. 135-162.

[21] G. M. MacDonald and B. A. Barry, "Difference FT-IR Study of a Novel Biochemical Preparation of Photosystem,” Biochemistry, Vol. 31, No. 40, 1992, pp. 9848-9853. doi:10.1021/bi00155a043 